\title{
TARGETING SPIKE PROTEIN OF SARS-COV-2 FOR DEVELOPMENT OF COVID-19 VACCINES AND THERAPEUTICS
}

\author{
G. N. Tanuj ${ }^{1}$, Anandu S. ${ }^{2}$, Khan Sharun ${ }^{3 *}$ (D), Kuldeep Dhama ${ }^{4 *}$ \\ ${ }^{1}$ Division of Veterinary Biotechnology, ICAR-Indian Veterinary Research Institute, Izatnagar, Bareilly, Uttar Pradesh, India \\ ${ }^{2}$ Division of Veterinary Parasitology, ICAR-Indian Veterinary Research Institute, Izatnagar, Bareilly, Uttar Pradesh, India \\ ${ }^{3}$ Division of Surgery, ICAR-Indian Veterinary Research Institute, Izatnagar, Bareilly, Uttar Pradesh, India. \\ ${ }^{4}$ Division of Pathology, ICAR-Indian Veterinary Research Institute, Izatnagar, Bareilly, Uttar Pradesh, India. \\ Received - September 25, 2020; Revision - October 15, 2020; Accepted - October 22, 2020 \\ Available Online October 23, 2020
}

DOI: http://dx.doi.org/10.18006/2020.8(Spl-1-SARS-CoV-2).S42.S56

\section{KEYWORDS \\ COVID-19 \\ SARS-CoV-2 \\ Spike protein \\ ACE2}

Vaccines

Therapeutics

\begin{abstract}
Coronavirus disease 2019 (COVID-19) was first reported in the sea-food market of Wuhan, China which and later declared as a pandemic. The novel coronavirus responsible for COVID-19 was later given the name severe acute respiratory syndrome coronavirus 2 (SARS-CoV-2) due to its close similarity with SARS-CoV. The entry of the virus is mediated through the interaction of spike glycoprotein with the host receptor angiotensin-converting enzyme 2 (ACE2). The Spike protein plays a pivotal role in SARS-CoV-2 infection as it is required for both receptor binding and viral fusion, hence the key target for neutralizing antibodies. Owing to its important role, Spike protein stands as the prime target for developing vaccines and therapeutics. The $\mathrm{S}$ glycoprotein carries the receptor-binding domain and the major $\mathrm{B}$ cell and $\mathrm{T}$ cell epitopes, which indicate that it is a potential target for vaccines and therapeutics. Several candidate vaccines have already entered into the clinical trials. The commonly employed vaccine platforms for COVID-19 include subunit, virus-like particles (VLPs), DNA, RNA, and viral vector-based platforms. The majority of these vaccine candidates target the Spike glycoprotein to elicit an efficient immune response. The safety profile and clinical efficacy of COVID-19 vaccines that are currently under trials are quite reassuring, but it is still way ahead from attaining commercial utility. In this review, we have highlighted the recent advances in S protein-based vaccine and anti-viral platforms along with their importance in prophylaxis and control of COVID-19.
\end{abstract}

* Corresponding author

E-mail: sharunkhansk@gmail.com (Khan Sharun); kdhama@rediffmail.com.com (Kuldeep Dhama)

Peer review under responsibility of Journal of Experimental Biology and Agricultural Sciences.

Production and Hosting by Horizon Publisher India [HPI] (http://www.horizonpublisherindia.in/).

All rights reserved.
All the articles published by Journal of Experimental Biology and Agricultural Sciences are licensed under a Creative Commons Attribution-NonCommercial 4.0 International License Based on a work at www.jebas.org.

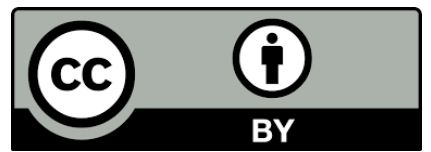




\section{Introduction}

Coronavirus disease 2019 (COVID-19) was first reported in late December of 2019 that originated from the sea-food market in Wuhan, China, and later became a global pandemic affecting over 38 million people worldwide and resulting in nearly 1.1 million deaths as of 13th October, 2020 (Chan et al., 2020; https://www.worldometers.info/coronavirus/; WHO, 2020a; Zhu et al., 2020a). The novel coronavirus responsible for COVID-19 was later given the name severe acute respiratory syndrome coronavirus 2 or SARS-CoV-2 (previously 2019-nCoV) due to its close similarity with SARS-CoV. Genomic characterization and phylogenetic analysis revealed that the novel coronavirus falls under the genus of Betacoronavirus lineage B ( $\mathrm{Lu}$ et al., 2020; Dhama et al., 2020a). COVID-19 associated deaths are the highest in three major countries, USA, Brazil, and India as compared to other countries (Shah et al., 2020).

Genomic analyses suggest bat as the most probable source of SARS-CoV-2 although further investigations are needed to confirm the origin of this novel virus (Malik et al., 2020). The genome of SARS-CoV-2 showed $80.6-81.1 \%$ and $51 \%$ similarity with SARS-CoVs and MERS-CoV, respectively at the nucleotide level (Sharun et al., 2020a). Compared to the previous outbreaks caused by Severe Acute Respiratory Syndrome coronavirus (SARS-CoV) and Middle East Respiratory Syndrome CoV (MERS-CoV), SARS-CoV-2 has very high transmission potential (Dhama et al., 2020a). This is evident from the very high rate of disease transmission in the human population as well as the increased spill over to other species such as dogs, cats, tigers, lions, and minks (Dhama et al., 2020b; RodriguezMorales et al., 2020a; Sharun et al., 2020b; Tiwari et al., 2020). Therefore, the current situation warrants the need for biosafety and biosecurity measures at all levels to control and prevent the transmission of SARS-CoV-2 among human beings (Ahmad et al., 2020; Sivaprasad et al., 2020).

The immediate release of SARS-CoV-2 whole genome sequence following the outbreak has enabled the research community to analyze and develop diagnostic tests, vaccines, and therapeutic strategies against the novel pathogens (Bilal et al., 2020; Rodriguez-Morales et al., 2020b). Researchers around the world are on the run for identifying SARS-CoV-2specific vaccines and therapeutics based on previous experience with zoonotic coronaviruses such as SARS-CoV and MERS-CoV (Dhama et al., 2020c; Frediansyah et al., 2020; Rubin et al., 2020). Although few of these candidate vaccines and therapeutics have shown promising results, it will take several months before we could confirm their benefits (Patel et al., 2020; Sharun et al., 2020c; Sharun et al., 2020d). In addition to the vaccines and small molecule therapeutics, antibody-based immunotherapeutic such as convalescent plasma, monoclonal antibodies, and neutralizing antibodies can be used to reduce the mortality in COVID-19 patients (Sharun et al., 2020e). Preliminary studies conducted for the evaluation of the therapeutic potential of SARS-CoV-2-specific vaccines and therapeutics have to be performed in an efficient animal model before they are used for clinical trials. Vaccines against SARS-CoV-2 are mainly evaluated using non-human primates such as Rhesus macaque (Macaca mulatta) and Cynomolgus macaque (Macaca fascicularis) (Faslu Rahman et al., 2020; Sharun et al., 2020b).

In this review, we emphasize the importance of Spike (S) protein as a target for designing vaccines and therapeutics against COVID19 and the recent advancements regarding the same.

\section{Structural and genomic organization}

SARS-CoV 2 is an enveloped virus with a positive-sense ssRNA genome of approximately $30 \mathrm{~kb}$ in size (Khailany et al., 2020). The angiotensin-converting enzyme 2 (ACE2) mediates entry into the host cell and is followed by the translation of genomic RNA via two open reading frames (ORFs); ORF1a and ORF 1b to produce non-structural proteins ( $\mathrm{Lu}$ et al., 2019; Kim et al., 2020). ORF1a and ORF1b produce PP1a and PP1b respectively, which are then cleaved into NSP-1 to 16 through proteolytic cleavage mediated by viral proteases: papain-like protease and 3C like protease (Masters, 2006). The replication-transcription complex mediates synthesis of negative strand RNA template, genomic RNA (gRNA) amplification and production of subgenomic RNA (sgRNA). Shorter sgRNA encode for conserved structural proteins Spike, Envelope, Membrane, Nucleocapsid and few other accessory proteins; whereas the genomic RNA is encapsulated and assembled (Khailany et al., 2020; Kim et al., 2020; Wu et al., 2020a; Hussain et al., 2020).

\section{Prefusion $S$ architecture}

Spike protein is a Class I fusion glycoprotein and exists as a homotrimer on the surface of virus. The host cell recognition and entry is mediated by Receptor Binding Domain (RBD) of $\mathrm{S}$ glycoprotein through ACE2 receptors on the host cells (Shang et al., 2020b; Wrapp et al., 2020). The metastable prefusion state of S protein undergoes large scale conformational changes following its receptor binding and cleavage (Walls et al., 2017). The Spike glycoprotein (S protein) consists of two subunits: S1 subunit responsible for host cell receptor binding and S2 subunit equipped with fusion machinery. The S1 subunit consists of the N-terminal domain, RBD, Subdomains SD1 and SD2. The fusion machinery comprises a Fusion Peptide (FP), Heptad repeats HR1 and HR2, Transmembrane domain (TD) and Cytoplasmic tail (CT) (Wrapp et al., 2020; Bangaru et al., 2020). 


\section{Receptor binding and Post fusion S2 trimer}

As mentioned earlier, the entry of SARS-CoV-2 is mediated by human ACE-2 receptor interaction with C-Terminal Domain (CTD) of $\mathrm{S}$ protein and occurs with a greater affinity than compared to the RBD of SARS-CoV (Wrapp et al., 2020; Wang et al., 2020b; Walls et al., 2020). Whereas, hACE2 binding affinity for SARS-CoV-2 spike is comparable or lower than the spike of SARS-CoV. This paradox is due to the fact that RBD of SARS-CoV is mostly in standing-up state but the SARS-CoV-2 RBD is mostly in its lying down state making it less accessible (Shang et al., 2020a). One more distinguishing feature of SARS-CoV-2 is the furin pre-activation of $S$ protein, which compensates for the hidden RBD and also enhances its entry into some cell types (Shang et al., 2020a). Earlier investigations on different coronaviruses revealed that the spike protein activation is an irreversible and tightly regulated mechanism that occurs at various sites on $\mathrm{S}$ protein-mediated by host proteases (Hulswit et al., 2016). The spike protein shifts from its pre-fusion state to a hairpin-like post-fusion state following the receptor binding and this is mediated by proteolytic cleavage at both the S1/S2 boundary and S2' (Cai et al., 2020). Unlike the previous corona viruses, SARS-CoV-2 harbors a polybasic cleavage site (underlined, SPRRAR $\downarrow S$ ) at the junction of S1 and S2 subunits and is believed to have contributed to the increased species to species transmission and cell-cell fusion (Coutard et al., 2020; Jaimes et al., 2020a). The presence of this polybasic cleavage site makes the $\mathrm{S}$ protein susceptible to a wide range of proteases along with furin TTSPs (Type II transmembrane serine proteases) like TMPRSS2, matriptase, cathepsins, and various other host cell like proteases can act on the two important cleavage sites, unequivocally important for the virus entry, hence can be evaluated as the potential targets for the development of vaccine and therapeutic against SARS-CoV-2 (Belouzard et al., 2012; Jaimes et al., 2020b; Hoffmann et al., 2020a).

Receptor binding destabilizes the prefusion state of $\mathrm{S}$ protein and sheds off the S1 subunit. This releases the S2 subunit from its structural constrains exposing the FP which can then insert itself into the host cell membrane (Cai et al., 2020). A bridge is formed between virus and host cell membranes mediated by a pre-hairpin intermediate of $\mathrm{S} 2$ subunit. The membrane fusion is initiated by the formation of 6-Helical Bundle (6-HB) through interaction between three HR1 and HR2 segments each. The high fusogenic activity of SARS-CoV-2 than the other SARS-like coronaviruses may be due to the enhanced interaction between HR1 and HR2 segments (Zhu et al., 2020b; Liu et al., 2004, Tang et al., 2020).

\section{SARS-CoV-2 Vaccine platforms based on S protein}

Various methods are currently being employed for the development of COVID-19 vaccines that use either the whole virus as in traditional methods like live-attenuated vaccines and inactivated vaccines or targets a specific portion of the virus. As in this case, the spike protein for the construction of modern vaccines using protein subunit, virus-like particles (VLPs), DNA, RNA and viral vectorbased platforms. Various COVID-19 vaccines targeting Spike protein and details of their clinical evaluation are listed in Table 1.

Spike protein is critical for the virus infection and a major contributor in inducing host immune response and neutralizing antibodies. Characterization of spike glycoprotein revealed the presence of numerous B cell and $\mathrm{T}$ cell epitopes making it a prime target for vaccine design (Du et al., 2009; Walls et al., 2020; Tian et al., 2020; Zheng \& Song, 2020; He et al., 2020). S based vaccines can be constructed using a full-length $\mathrm{S}$ protein, RBD, S1 and S2 subunits.

Candidate vaccines targeting full length S protein or S1 subunit may elicit a potent immune response but have safety concerns due to the competition between neutralizing and non-neutralizing epitopes, raising concerns about the efficacy and safety of vaccines that contain a full-length spike protein (Du et al., 2009; Wang et al., 2016). Studies have showed that that recombinant full-length S-based vaccines produced an immune enhancement in vaccinated animals and a biased Th2 type response leading to the poor outcome of disease (Tseng et al., 2012; Zhu et al., 2013). This may lead to antibody-dependent enhancement (ADE) due to the heterogeneity of antigenic epitopes (Tetro, 2020). At present, there is no clinical proof supporting the occurrence of ADE with SARSCoV-2. However, published data suggest that it bears great potential for ADE in SARS-CoV-2 (Ulrich et al., 2020).

One such strategy to overcome ADE is to limit the vaccine designs only the important antigenic epitopes. RBD happens to be one of the choices as it does not contain any such immunodominant regions that can produce non-neutralizing antibodies. But vaccine candidates targeting RBD may require the addition of specific adjuvants and repeated doses due to its comparatively low immunogenicity (Dai et al., 2020). Another choice is to target $S 1$ as it contains a large set of neutralizing epitopes that are present outside the RBD and therefore more immunogenic (Wang et al., 2020d). The S2 subunit is a highly conserved region and can elicit a cellular immune response, but there are different speculations about its potency to develop neutralizing antibodies (Keng et al., 2005; Li et al., 2013; He et al., 2020). However, due to its high sequence homology, the S2 subunit can be considered as a potential target for developing universal vaccines against divergent $\mathrm{CoV}$ strains.

\section{Considerations for vaccine development}

Multiple vaccine platforms have been employed in the development of SARS-CoV-2 vaccines, advantages and disadvantages of each platform are discussed in Table 1. Vaccine development is a laborious and complicated process; and in such 
Table 1 Spike protein-based COVID-19 vaccine candidates that are currently undergoing clinical trials (Ref: Foged et al., 2011;

Choi \& Chang., 2013; Pardi et al., 2018; Li \& Petrovsky, 2016; WHO, 2020b; Pandey et al., 2020; Samrat et al., 2020;

Bar-Zeev \& Moss, 2020; Fuller \& Berglund, 2020; Jeyanathan et al., 2020)

\begin{tabular}{|c|c|c|c|}
\hline Type of technology & Vaccine/Manufacturer & Clinical trial/Stage & Type of Candidate \\
\hline \multirow{4}{*}{$\begin{array}{l}\text { Protein subunit } \\
\text { Advantages: } \\
\text { Can target a defined region of } \\
\text { immunogen, availability of } \\
\text { various delivery systems, } \\
\text { convenient large-scale production, } \\
\text { safer and more stable so can be } \\
\text { given even to immunosuppressed } \\
\text { people }\end{array}$} & $\begin{array}{c}\text { Anhui Zhifei Longcom } \\
\text { Biopharmaceutical/Institute of } \\
\text { Microbiology, Chinese Academy of } \\
\text { Sciences }\end{array}$ & $\begin{array}{l}\text { (Phase 1)/ NCT04445194 } \\
\text { (Phase 2)/ NCT04466085 }\end{array}$ & $\begin{array}{l}\text { RBD-dimer based recombinant } \\
\text { protein }\end{array}$ \\
\hline & $\begin{array}{c}\text { University of } \\
\text { Queensland/CSL/Seqirus }\end{array}$ & $\begin{array}{c}(\text { Phase 1)/ } \\
\text { ACTRN12620000674932p }\end{array}$ & $\begin{array}{l}\text { Molecular clamp stabilized } \\
\text { Spike protein with MF59 } \\
\text { adjuvant }\end{array}$ \\
\hline & Vaxine Pty Ltd and Medytox & (Phase 1)/ NCT04453852 & $\begin{array}{l}\text { Recombinant spike protein } \\
\text { with Advax adjuvant }\end{array}$ \\
\hline & Kentucky Bioprocessing, Inc & (Phase 1/2)/ NCT04473690 & Based on RBD \\
\hline \multirow{6}{*}{$\begin{array}{l}\text { Disadvantages: } \\
\text { Low immunogenicity, } \\
\text { requirement of adjuvant, typically } \\
\text { require multiple doses, risk of } \\
\text { denaturation of a protein antigen, } \\
\text { relatively expensive }\end{array}$} & $\begin{array}{l}\text { Clover Biopharmaceuticals } \\
\text { Inc./GSK/Dynavax }\end{array}$ & (Phase 1)/ NCT04405908 & $\begin{array}{l}\text { Native like Trimeric subunit } \\
\text { Spike Protein }\end{array}$ \\
\hline & NVXCoV2373; Novavax & (Phase 1/2) /NCT04368988 & $\begin{array}{l}\text { Full-length recombinant SARS } \\
\text { CoV-2 glycoprotein } \\
\text { nanoparticle r vaccine } \\
\text { adjuvanted with Matrix M }\end{array}$ \\
\hline & $\begin{array}{c}\text { Medigen Vaccine Biologics } \\
\text { Corporation/NIAID/Dynavax }\end{array}$ & (Phase 1)/NCT04487210 & $\mathrm{S}-2 \mathrm{P}$ protein $+\mathrm{CpG} 1018$ \\
\hline & Instituto Finlay de Vacunas, Cuba & (Phase 1)/ IFV/COR/04 & RBD + Adjuvant \\
\hline & $\begin{array}{l}\text { West China Hospital, Sichuan } \\
\text { University }\end{array}$ & $\begin{array}{c}\text { (Phase 1)/ } \\
\text { ChiCTR2000037518 }\end{array}$ & $\begin{array}{l}\text { RBD (baculovirus production } \\
\text { expressed in Sf9 cells) }\end{array}$ \\
\hline & $\begin{array}{l}\text { FBRI SRC VB VECTOR, } \\
\text { Rospotrebnadzor, Koltsovo }\end{array}$ & (Phase 1)/NCT04527575 & Peptide \\
\hline \multirow{4}{*}{$\begin{array}{l}\text { DNA } \\
\text { Advantages: } \\
\text { Noninfectious; stable and easy to } \\
\text { produce, cost-effective; induces } \\
\text { effective innate immune response; } \\
\text { effective induction of CTL; } \\
\text { induces T cell and B cell- } \\
\text { mediated immunity }\end{array}$} & $\begin{array}{c}\text { INO-4800; Inovio } \\
\text { Pharmaceuticals/International } \\
\text { Vaccine Institute }\end{array}$ & $\begin{array}{c}\text { (Phase 1/2)/ NCT04336410, } \\
\text { NCT04447781 }\end{array}$ & $\begin{array}{l}\text { DNA plasmid vaccine with } \\
\text { electroporation }\end{array}$ \\
\hline & Osaka University/AnGes/Takara Bio & (Phase 1/2)/ NCT04463472 & $\begin{array}{l}\text { DNA } \\
\text { vaccine + adjuvant }\end{array}$ \\
\hline & Zydus Cadila & $\begin{array}{c}\text { (Phase 1/2)/ } \\
\text { CTRI/2020/07/026352 } \\
\end{array}$ & DNA plasmid vaccine \\
\hline & Genexine Consortium & (Phase 1/2)/ NCT04445389 & DNA Vaccine (GX-19) \\
\hline $\begin{array}{l}\text { Disadvantages: } \\
\text { Lower immunogenicity in humans } \\
\text { than compared to animal models; } \\
\text { require additional administration } \\
\text { device; chances of integration into } \\
\text { the human genome }\end{array}$ & $\begin{array}{l}\text { bacTRL-Spike; Symvivo } \\
\text { Corporation }\end{array}$ & (Phase 1)/ NCT04334980 & $\begin{array}{l}\text { Bifidobacterium longum } \\
\text { engineered to deliver plasmids } \\
\text { containing synthetic DNA } \\
\text { encoding spike protein }\end{array}$ \\
\hline \multirow{4}{*}{$\begin{array}{l}\text { RNA } \\
\text { Advantages: } \\
\text { Non-infectious, non-integrating } \\
\text { platform; rapid and stable } \\
\text { production; induces effective } \\
\text { innate immune response; induces } \\
\mathrm{T} \text { cell and B cell-mediated } \\
\text { immunity; inherent } \\
\text { immunogenicity can be regulated }\end{array}$} & mRNA-1273;Moderna/NIAID & $\begin{array}{l}\text { (Phase 1)/ NCT04283461 } \\
\text { (Phase 2)/ NCT04405076 } \\
\text { (Phase 3)/ NCT04470427 }\end{array}$ & LNP-encapsulated mRNA \\
\hline & BioNTech/Fosun Pharma/Pfizer & $\begin{array}{c}\text { (Phase 1/2)/ } \\
\text { ChiCTR2000034825 } \\
\text { (Phase 3)/ NCT04368728 } \\
\end{array}$ & 3 LNP-mRNAs \\
\hline & Curevac & $\begin{array}{l}\text { (Phase 1)/NCT04449276 } \\
\text { (Phase 2)/NCT04515147 } \\
\end{array}$ & mRNA \\
\hline & Arcturus/Duke-NUS & (Phase 1/2)/ NCT0448057 & $\begin{array}{l}\text { Self-replication of mRNA with } \\
\text { nanoparticle delivery system }\end{array}$ \\
\hline $\begin{array}{l}\text { Disadvantages: } \\
\text { Lower immunogenicity in humans } \\
\text { than compared to animal models; } \\
\text { concerns regarding instability, } \\
\text { require efficient carrier methods }\end{array}$ & Imperial College London & $\begin{array}{c}\text { (Phase 1)/ } \\
\text { ISRCTN17072692 }\end{array}$ & LNP-nCoVsaRNA \\
\hline
\end{tabular}

Journal of Experimental Biology and Agricultural Sciences

http://www.jebas.org 


\begin{tabular}{|c|c|c|c|}
\hline Type of technology & Vaccine/Manufacturer & Clinical trial/Stage & Type of Candidate \\
\hline \multirow{2}{*}{$\begin{array}{l}\text { Viral vector-based } \\
\text { Advantages: } \\
\text { Effective stimulation of both } \\
\text { humoral and cellular immune } \\
\text { response; better presentation of } \\
\text { antigen; easily engineered; broad } \\
\text { range of cellular tropism }\end{array}$} & University of Oxford/AstraZeneca & $\begin{array}{l}\text { (Phase 1/2)/ NCT04324606 } \\
\text { (Phase 2)/ 2020-001228-32 } \\
\text { (Phase 3)/ ISRCTN89951424 }\end{array}$ & $\begin{array}{l}\text { Non-Replicating Viral Vector; } \\
\text { ChAdOx1 platform }\end{array}$ \\
\hline & $\begin{array}{c}\text { CanSino Biological Inc./ } \\
\text { Beijing Institute of Biotechnology }\end{array}$ & $\begin{array}{c}\text { (Phase 1)/ } \\
\text { ChiCTR2000030906 } \\
\text { (Phase 2)/ } \\
\text { ChiCTR2000031781 } \\
\text { (Phase 3)/NCT04526990 } \\
\end{array}$ & $\begin{array}{l}\text { Non-Replicating Viral } \text { Vector; } \\
\text { Adenovirus Type } 5 \text { Vector } \\
\text { encodes for a full-length S protein }\end{array}$ \\
\hline \multirow{4}{*}{$\begin{array}{l}\text { Disadvantages: } \\
\text { Pre-existing immunity; need of co- } \\
\text { infection with helper virus for some } \\
\text { viral vectors; limited host range; } \\
\text { limited carrying capacity; chance of } \\
\text { persistent or latent infection; risk of } \\
\text { recombination }\end{array}$} & Gamaleya Research Institute & $\begin{array}{c}\text { (Phase 1)/ NCT04436471, } \\
\text { NCT04437875 } \\
\text { (Phase 3)/NCT045303 }\end{array}$ & $\begin{array}{l}\text { Non-Replicating Viral Vector; } \\
\text { Adeno-based (rAd26-S+rAd5-S) }\end{array}$ \\
\hline & Janssen Pharmaceutical Companies & $\begin{array}{c}\text { (Phase 1/2)/NCT04436276 } \\
\text { (Phase 3)/NCT04505722 }\end{array}$ & $\begin{array}{l}\text { Non-Replicating Viral Vector; } \\
\text { Ad26COVS1 }\end{array}$ \\
\hline & ReiThera/LEUKOCARE/Univercells & (Phase 1)/NCT04528641 & $\begin{array}{l}\text { Non-Replicating Viral Vector; } \\
\text { Replication defective Simian } \\
\text { Adenovirus (GRAd) encoding S }\end{array}$ \\
\hline & $\begin{array}{c}\text { Institute Pasteur/Themis/Univ. of } \\
\text { Pittsburg CVR/Merck Sharp \& } \\
\text { Dohme } \\
\end{array}$ & (Phase 1)/NCT04497298 & $\begin{array}{l}\text { Replicating Viral Vector; } \\
\text { Measles-vector based }\end{array}$ \\
\hline
\end{tabular}

critical times a pandemic paradigm can be employed for better results. There are several considerations for an effective vaccine design like optimizing antigen design, host-related factors, duration of immunity, and selection of good animal models and choice of adjuvants (Lurie et al., 2020). Nanotechnology can significantly contribute in the development of modern vaccines. Nanomaterials are ideal materials for delivering antigens and can be used as adjuvants in the vaccines. The first vaccine candidate for COVID-19 that was launched into clinical trials was in fact an mRNA-based vaccine that was delivered via lipid nanoparticles (Shin et al., 2020). mRNA-1273 is the lipid nanoparticleencapsulated vaccine candidate that encodes the SARS-CoV-2 S glycoprotein (Jackson et al., 2020). Preliminary in vivo study of mRNA-1273 vaccine were conducted in non-human primates (Rhesus macaque model) and the vaccine was found to induce robust SARS-CoV-2 neutralizing activity (Corbett et al., 2020). In the clinical trial involving older adults, immunization with mRNA1273 vaccine was only associated with mild to moderate side effects. The side effects mostly included chills, headache, myalgia, fatigue, and pain at the injection site and were mostly observed following the second immunization (Anderson et al., 2020). NVX$\mathrm{CoV} 2373$ is a recombinant SARS-CoV-2 nanoparticle vaccine that contains trimeric full-length SARS-CoV-2 spike glycoproteins (Keech et al., 2020). Findings from the clinical trial indicates that NVX-CoV2373 elicited good immune responses and appeared to be safe (ClinicalTrials.gov number, NCT04368988).

Safety profiles and clinical efficacy regarding COVID-19 vaccines under trials are quite reassuring, but still it is a long way ahead to form a clear point on safety and efficacy of each vaccine candidate. Although there has been a high demand for an effective COVID-19 vaccine, the standards for vaccine development have remained unaltered. Licensing a vaccine should be based on short term and long-term protection from disease, effect on rate of transmission, safety and efficacy follow-ups (Bar-Zeev \& Inglesby, 2020; Heaton, 2020). Host-related factors like target groups, duration of observation, clinical endpoints, ADE, seroprevalence, pre existing immunity and cross reactivity must be considered to establish a proper efficacy model for vaccine design (Lee \& McGeer, 2020).

One of the major concerns with vaccine modality is the large-scale manufacture of billions of doses. Each vaccine platform has its own pros and cons with large scale manufacturing which may depend on various factors like durability, productivity, storage, distribution, dose requirement, vehicles or adjuvants, yield and cost of production. Manufacturing of large number of doses is a challenge for few modern platforms like nucleic acid and viral vector vaccines (DeFrancesco, 2020). During the early days of pandemic, we have seen conflicts regarding distribution of health care equipment and pharmaceuticals. This led to the case of medical protectionism and it is still continuing. Care must be taken to avoid such situations during vaccine development and distribution stages. A unified global governance, exchange of cross trail data and technology and a coordinated approach between government and manufacturing agencies are crucial for the development of a pandemic vaccine (The Lancet, 2020).

\section{S-protein based therapeutics}

Apart from the Spike protein-based vaccines, researchers are also focusing on therapeutics that target $\mathrm{S}$ protein and its interaction with the ACE2 receptor (Frediansyah et al., 2020; Dhama et al., 2020a). These include peptides and peptidomimetics against Spike-ACE2 interaction, host protease, and fusion inhibitors along with monoclonal antibodies targeting major epitopic determinants on the $\mathrm{S}$ protein. Few of which have already shown promising results in preclinical trials and the rest continue to be the potential targeting for developing COVID-19 therapeutics (Sharun et al., 2020a). 


\section{Therapeutics targeting Spike-ACE2 interaction}

The main entry point of SARS-CoV-2 is via the interaction of RBD with host ACE2 and remains the major target for inhibiting the entry of the virus into host cells. Several therapeutics including recombinant $\mathrm{RBD}$, recombinant $\mathrm{ACE} 2$, and peptides targeting several regions on ACE2 and RBD are currently being evaluated.

The peptidase domain (PD) $\alpha 1$ helix of ACE2 is essential for its interaction with RBD (Zhang et al., 2020). Zhang et al. chemically synthesized a 23-mer peptide fragment from this region called SBP1 which acts as a peptide binder that can effectively inhibit the RBD-ACE2 interaction. The peptides to be effective must bind to three regions on the RBD namely, Gly485/Phe486/Asn487, Gln493, and Gln498/Thr500/Asn501n (Barh et al., 2020). Computational studies led by several teams have revealed the presence of key amino acid stretches on RBD and ACE2 required for the interaction and can be considered as potential targets for the development of peptide-based therapeutics (Barh et al., 2020; Huang et al., 2020a; Han \& Král, 2020; Vanpatten et al., 2020). AlphaLISA assay can be used to study protein-protein interactions for screening peptide-based ACE2-RBD therapeutics (Hanson et al., 2020). Inhibitors 1-4 (Han \& Král, 2020) extracted from ACE2 yielded promising results in blocking RBD-ACE2 interaction. The binding affinity of such inhibitors can be improved by attaching the peptide inhibitors with clusters, dendrimers, or nanoparticles (Han \& Král, 2020). Some of the important therapeutic peptides designed against SARS-CoV include P6, RBD-11b, S(471-503) and SP-10 that targets the interaction between RBD and ACE2, thereby preventing the entry of the virus into host cells (Hu et al., 2005; Ho et al., 2006; Han et al., 2006; Struck et al., 2012).

In silico screening approach used for repurposing drugs against SARSCoV-2 and ACE2 receptor interface revealed numerous potential candidates that can be used as antiviral therapeutics (Choudhary et al., 2020). Alexpandi et al. proposed that rilapladib is the only quinolone that can target RBD interface between Spike and ACE2 (Alexpandi et al., 2020). Simeprevir and Lumacaftor interact with the side chains residues on RBD binding pocket thereby preventing RBD-ACE2 binding in silico (Trezza et al., 2020). Use of exogenous ACE2 in the form of recombinant-human angiotensin-converting enzyme 2 (rhACE2) can inhibit the entry of SARS-CoV-2 into host cells as well as decrease the incidence of its complications like ARDS, thereby rendering beneficial effects in organs like kidneys and lungs (Pang et al., 2020; Roshanravan et al., 2020; Alhenc-Gelas \& Drueke, 2020).

Various other drugs like angiotensin receptor blockers (ARB), Calmodulin antagonists that inhibit CALM-ACE2 interaction and selective estrogen receptor modulators can also be considered for modulating ACE2 mediated entry of SARS-CoV-2 (Ragia \& Manolopoulos, 2020). Angiotensin-(1-7), a cardioprotective angiotensin peptide; ACE inhibitors, ARBs and anti-hyperlipidemic like Simvastatin and Atorvastatin are in various phases of clinical trials as a part of therapeutics targeting the RASS-ACE2-AT1 receptor system thereby inhibiting ACE2 interaction with spike protein and also to reduce the risk of ARDS in COVID-19 patients (Peiró \& Moncada, 2020; Talreja et al., 2020; Katsiki et al., 2020; Poduri et al., 2020).

\section{Therapeutics targeting Cleavage $S$ protein}

As mentioned earlier, various host proteases like TMPRSS2, furin and cathepsins are required for the priming of $S$ protein that is required for the fusion and entry processes (Bestle et al., 2020). One of the main proteases of SARS-CoV-2 is the TMPRSS2. Recent studies based on in silico screening revealed that topoisomerase I inhibitor, Rubitecan and Loprazolam, a benzodiazepine along with two other novel drug-like compounds displayed promising inhibitory effect on TMPRSS2 generated via homology modeling approach (Elmezayen et al., 2020). Owing to their known actions and already established safety profile, they can be used as candidate drugs against COVID-19 infection (Sternberg et al., 2020). Several therapeutic agents that target TMPRSS2 have successfully inhibited the priming process in in vitro analysis (Sanders et al., 2020; Yamamoto et al., 2020; Hoffmann et al., 2020b; Bittmann et al., 2020). Clinical trials are being conducted to evaluate the therapeutic effects of TMPRSS2 inhibitors like Camostat mesylate, Nafamostat mesylate and Bromhexine against TMPRSS2 mediated entry of SARS-CoV-2 (Cannalire et al., 2020).

Cathepsins, especially CatL are essential for the cleavage of S1 subunit in acidic lysosomal and endosomal compartments and thereby a potential target in modulating endosome mediated SARSCoV-2 entry (Liu et al., 2020; Ou et al., 2020). Although there are no CatL/B inhibitors that are undergoing clinical trials, the preferential CatL inhibitors like CID 23631927 and CLIK-148, MDL28170, K11777, and E-64d have shown promising results in the inhibition of Cathepsin mediated viral entry (Cannalire et al., 2020).

Along with TMPRSS2, furin remains an important protease and is abundantly found in various organs. The presence of a furin cleavage site most likely increases the pathogenicity and cell tropism of SARS-CoV-2. Unfortunately, potent serine protease inhibitors are poor furin inhibitors, therefore we need to develop broad-spectrum protease inhibitors or cocktails containing both TMPRSS2 and furin inhibitors for effective modulation of $\mathrm{S}$ protein priming (Barile et al., 2020). Furin inhibitors like decanoyl-RVKR-chloromethyl ketone (CMK) and naphthofluorescein inhibited both cleavage and cytopathic effect in SARS-CoV-2 infected cells (Cheng et al., 2020). Furin and furin-like several enzyme inhibitors have already been elucidated for their metabolic and antiviral effects, including HexaD-arginine (D6R), PI8, $\alpha$-1-PDX ( $\alpha 1$-antitrypsin Portland), and MI701 can be considered for prevention and control strategies against COVID-19 (Dahms et al., 2017; Braun \& Sauter, 2019; Hasan et al., 2020, Huang et al., 2020b). 


\section{Therapeutics targeting Fusion-active core formation}

Currently, available SARS-CoV and MERS-CoV based antifusogenics include HR2-8, CP-1, HR1-1, HR2-18, P6, P8, P10, SR9, HR2P, P1, HR2P-M2 and P21S10 (Bosch et al., 2003; Liu et al., 2004; Zheng et al., 2005; Ujike et al., 2008; Gao et al., 2013; Yuan et al., 2014; Lu et al., 2014; Wang et al., 2018; Xia et al., 2019;). A novel peptide, 2019-nCoV-HR2P successfully inhibited SARS-CoV-2 pseudovirus infection (Xia et al., 2020). Apart from this, several pan-coronavirus fusion inhibitors like OC43-HR2P, EK1, and EK1C4 inhibit human coronavirus infection by targeting HR1 on the S2 subunit (Wang et al., 2020c). However, the effect of these fusion inhibitors needs to be elucidated based on in vivo studies. Recent research using drug repurposing studies revealed that four compounds namely phthalocyanine, hypericin, TMC-647055 and quarfloxin can be used as antiviral agents against SARS-CoV-2, as they inhibit the fusion of S protein with the host cells (Romeo et al., 2020). In addition to these, an HIV protease inhibitor called nelfinavi mesylate (Viracept) inhibits Spike mediated membrane fusion along with proteolytic cleavage of $\mathrm{S}$ within the cells (Musarrat et al., 2020).

Among coronaviruses, S2 subunit of the S protein is highly conserved and therefore a potential candidate for developing pancoronavirus vaccines and therapeutics (Walls et al., 2020). Fusion inhibitors targeting mainly the HR2 region of the S2 subunit represent a promising therapeutic strategy against human coronaviruses. However, the effect of these fusion inhibitors needs to be elucidated based on in vivo studies.

\section{Antibodies targeting Spike protein}

Spike protein is the major antigenic determinant of coronaviruses and it is the key target for host immune response. Neutralizing antibodies generated against the spike protein can provide protective immunity by inhibiting receptor recognition and membrane fusion. After the outbreak of SARS-CoV, numerous antibodies were produced against various regions of $\mathrm{S}$ protein like $\mathrm{RBD}$, whole $\mathrm{S} 1$ or $\mathrm{S} 2$ that showed promising results in the in vitro studies (Table 2). Unfortunately, none of these neutralizing antibodies entered into the clinical evaluation.

Although the repository contains a number of neutralizing antibodies (nAbs) against SARS-CoV, very few turned out to be effective against SARS-CoV-2. One such example is CR3022, which was able to potently neutralize SARS-CoV-2 despite being a SARS-CoV-specific Ab (Tian et al., 2020). In addition to these, nAbs generated against the spike protein of MERS-CoV successfully inhibited the MERS infection in both in vitro and in vivo systems (Du et al., 2017; Zhou et al., 2019). There is a need for developing broad-spectrum neutralizing antibodies with crossreactivity/cross-neutralization capacity against various human coronaviruses. Despite the speculations around safety concerns and efficacy, rapid production at a reasonable cost make nAbs, a potential candidate for the prophylaxis and control of COVID-19.

\section{Conclusion and Future Prospects}

Spike protein plays a pivotal role in SARS-CoV-2 infection as it is required for both receptor binding and viral fusion. $\mathrm{S}$ protein determines the cell tropism and also acts as the key target for neutralizing antibodies, hence the prime candidate for designing vaccines and therapeutics. Over 33 vaccines entered into the clinical trial phase and more than 140 vaccine candidates are currently in their pre-clinical evaluation breaking all the records and setting a pace in this era of modern vaccinology. A major chunk of these candidates targets the $\mathrm{S}$ protein to elicit an efficient immune response. S protein carries the RBD and also major B cell and $\mathrm{T}$ cell epitopes, hence making it is a potential candidate for the development of vaccines. Apart from the traditional platforms like live attenuated and inactivated vaccines, researchers have adopted recombinant genetic technology for designing COVID-19 vaccines. Various factors like immunogenicity, rate and cost of production, delivery systems, ADE have to be considered for developing an effective vaccine system.

To date, no vaccine has been approved for use against human coronaviruses. Meanwhile, various peptides and small-molecule inhibitors based on $\mathrm{S}$ protein can be adopted to modulate SARSCoV-2 entry into host cells. Most of which are familiar to us with known safety profiles and metabolic effects. Most of the therapeutics strategies discussed here have shown promising results in controlling

Table 2 Potential Neutralizing Abs targeting spike protein of SARS-CoV and SARS-CoV-2

\section{Corona virus Neutralizing Antibody (nAb) name}

S230.15, m396, S109.8, S227.14, S230.15, 80R, CR3022,

SARS-CoV CR3014, 33G4,35B5，30F9， 68, 201，4D4， F26G18,

F26G19, 1A9, B1, 1F8, 5E9

B38, H4, 47D11, CR3022, 311mab-31B5, 311mab-32D4, n3130, n3088, S309, P2C-1F11, P2B-2F6, 4A8
Sui et al., 2004; Greenough et al., 2005; Duan et al., 2005; He et al., 2006; Lip et al., 2006; Coughlin et al., 2007; Zhu et al., 2007; Rockx et al., 2008; Berry et al., 2010; Elshabrawy et al., 2012; Ng et al., 2014; Tian et al., 2020

Wang et al., 2020a; Wu et al., 2020b; Tian et al., 2020; Chen et al., 2020; Wu et al., 2020c; Pinto et al., 2020; Ju et al., 2020; Chi et al., 2020

Journal of Experimental Biology and Agricultural Sciences

http://www.jebas.org 
COVID-19 infection in vitro and continue to be the same in clinical evaluation too. Host protease inhibitors and antifusogenics seem to be potential candidates for diminishing viral entry yet varying results are seen with different classes of inhibitors. The successful strategy in such cases can be achieved by using a cocktail of agents to boost their individual properties. Neutralizing antibodies raised against different regions of spike protein remain an important focus in prophylaxis and control of COVID-19.

Further focus on structural and immunological aspects can aid in the designing of better vaccines and antiviral agents. The S2 subunit is highly conserved among coronaviruses and therefore can be targeted for designing vaccines or therapeutics against a broad range of coronaviruses. With the recent fruitful outcomes in different phases of clinical evaluation, $S$ protein-based vaccine and therapeutic platform may help us to overcome the pandemic in the coming days.

\section{Acknowledgments}

All the authors acknowledge and thank their respective Institutes and Universities.

\section{Funding}

This compilation is a review article written by its authors and required no substantial funding to be stated.

\section{Disclosure statement}

All authors declare that there exist no commercial or financial relationships that could, in any way, lead to a potential conflict of interest.

\section{References}

Ahmad T, Haroon, Dhama K, Sharun K, Khan FM, Ahmed I, Tiwari R, Musa TH, Khan M, Bonilla-Aldana DK, J RodriguezMorales A, Hui J (2020) Biosafety and biosecurity approaches to restrain/contain and counter SARS-CoV-2/COVID-19 pandemic: a rapid-review. Turkish Journal of Biology 44(3):132-145. doi: 10.3906/biy-2005-63.

Alexpandi R, De Mesquita JF, Pandian SK, Ravi AV (2020) Quinolines-Based SARS-CoV-2 3CLpro and RdRp Inhibitors and Spike-RBD-ACE2 Inhibitor for Drug-Repurposing Against COVID19: An in silico Analysis. Frontiers in Microbiology 11:1796.

Alhenc-Gelas F, Drueke TB (2020) Blockade of SARS-CoV-2 infection by recombinant soluble ACE2. Kidney International 97(6):1091-1093.

Anderson EJ, Rouphael NG, Widge AT, Jackson LA, Roberts PC, Makhene M, Chappell JD, Denison MR, Stevens LJ, Pruijssers AJ, McDermott AB, Flach B, Lin BC, Doria-Rose NA, O'Dell S,
Schmidt SD, Corbett KS, Swanson PA 2nd, Padilla M, Neuzil KM, Bennett H, Leav B, Makowski M, Albert J, Cross K, Edara VV, Floyd K, Suthar MS, Martinez DR, Baric R, Buchanan W, Luke CJ, Phadke VK, Rostad CA, Ledgerwood JE, Graham BS, Beigel JH; mRNA-1273 Study Group (2020) Safety and Immunogenicity of SARS-CoV-2 mRNA-1273 Vaccine in Older Adults. New England Journal of Medicine. DOI: 10.1056/NEJMoa2028436.

Bangaru S, Ozorowski G, Turner HL, Antanasijevic A, Huang D, Wang X, Torres JL, Diedrich JK, Tian JH, Portnoff AD, Patel N, Massare MJ, Yates JR, Nemazee D, Paulson JC, Glenn G, Smith G, Ward AB (2020) Structural analysis of full-length SARS-CoV2 spike protein from an advanced vaccine candidate. bioRxiv : the preprint server for biology 2020.08.06.234674.

Barh D, Tiwari S, Silva Andrade B, Giovanetti M, Almeida Costa E, Kumavath R, Ghosh P, Góes-Neto A, Carlos Junior Alcantara L, Azevedo V (2020) Potential chimeric peptides to block the SARSCoV-2 spike receptor-binding domain. F1000Research 9:576.

Barile E, Baggio C, Gambini L, Shiryaev SA, Strongin AY, Pellecchia M (2020) Potential Therapeutic Targeting of Coronavirus Spike Glycoprotein Priming. Molecules 25(10):2424.

Bar-Zeev N, Inglesby T (2020) COVID-19 vaccines: early success and remaining challenges. Lancet 396(10255):868-869.

Bar-Zeev N, Moss WJ (2020) Encouraging results from phase 1/2 COVID-19 vaccine trials. Lancet 396(10249):448-449.

Belouzard S, Millet JK, Licitra BN, Whittaker GR (2012) Mechanisms of coronavirus cell entry mediated by the viral spike protein. Viruses 4(6):1011-33.

Berry JD, Hay K, Rini JM, Yu M, Wang L, Plummer FA, Corbett CR, Andonov A (2010) Neutralizing epitopes of the SARS-CoV Sprotein cluster independent of repertoire, antigen structure or $\mathrm{mAb}$ technology. MAbs 2(1):53-66.

Bestle D, Heindl MR, Limburg H, Van Lam van T, Pilgram O, Moulton H, Stein DA, Hardes K, Eickmann M, Dolnik O, Rohde C, Klenk HD, Garten W, Steinmetzer T, Böttcher-Friebertshäuser E (2020) TMPRSS2 and furin are both essential for proteolytic activation of SARS-CoV-2 in human airway cells. Life Science Alliance 3(9):e202000786.

Bilal M, Khan MI, Nazir MS, Ahmed I, Iqbal H (2020) Coronaviruses and COVID-19-Complications and Lessons Learned for the Future. Journal of Pure and Applied Microbiology 14(suppl 1):725-731 .

Bittmann S, Weissenstein A, Villalon G, Moschuring-Alieva E, Luchter E (2020) Simultaneous Treatment of COVID-19 With 
Serine Protease Inhibitor Camostat and/or Cathepsin L Inhibitor? Journal of Clinical Medicine Research 12(5):320-322.

Bosch BJ, van der Zee R, de Haan CA, Rottier PJ (2003) The coronavirus spike protein is a class I virus fusion protein: structura and functional characterization of the fusion core complex. Journal of Virology 77(16):8801-11.

Braun E, Sauter D (2019) Furin-mediated protein processing in infectious diseases and cancer. Clinical and Translational Immunology 8(8):e1073.

Cai Y, Zhang J, Xiao T, Peng H, Sterling SM, Walsh RM Jr, Rawson S, Rits-Volloch S, Chen B (2020) Distinct conformational states of SARS-CoV-2 spike protein. Science 369(6511):1586-1592.

Cannalire R, Stefanelli I, Cerchia C, Beccari AR, Pelliccia S, Summa V (2020) SARS-CoV-2 Entry Inhibitors: Small Molecules and Peptides Targeting Virus or Host Cells. International Journal of Molecular Sciences 21(16), E5707

Chan JF, Yuan S, Kok KH, To KK, Chu H, Yang J, Xing F, Liu J, Yip CC, Poon RW, Tsoi HW, Lo SK, Chan KH, Poon VK, Chan WM, Ip JD, Cai JP, Cheng VC, Chen H, Hui CK, Yuen KY (2020) A familial cluster of pneumonia associated with the 2019 novel coronavirus indicating person-to-person transmission: A study of a family cluster. Lancet 395, 514-523.

Chen X, Li R, Pan Z, Qian C, Yang Y, You R, Zhao J, Liu P, Gao L, Li Z, Huang Q, Xu L, Tang J, Tian Q, Yao W, Hu L, Yan X, Zhou X, Wu Y, Deng K, Zhang Z, Qian Z, Chen Y, Ye L (2020) Human monoclonal antibodies block the binding of SARS-CoV-2 spike protein to angiotensin converting enzyme 2 receptor. Cellular \& Molecular Immunology 17(6), 647-649.

Cheng YW, Chao TL, Li CL, Chiu MF, Kao HC, Wang SH, Pang YH, Lin CH, Tsai YM, Lee WH, Tao MH, Ho TC, Wu PY, Jang LT, Chen PJ, Chang SY, Yeh SH (2020) Furin Inhibitors Block SARS-CoV-2 Spike Protein Cleavage to Suppress Virus Production and Cytopathic Effects. Cell Reports 108254.

Chi X, Yan R, Zhang J, Zhang G, Zhang Y, Hao M, Zhang Z, Fan P, Dong Y, Yang Y, Chen Z, Guo Y, Zhang J, Li Y, Song X, Chen Y, Xia L, Fu L, Hou L, Xu J, Yu C, Li J, Zhou Q, Chen W (2020) A neutralizing human antibody binds to the $\mathrm{N}$-terminal domain of the Spike protein of SARS-CoV-2. Science 369(6504):650-655.

Choi Y, Chang J (2013) Viral vectors for vaccine applications. Clinical and experimental vaccine research 2(2), 97-105.

Choudhary S, Malik YS, Tomar S (2020) Identification of SARSCoV-2 Cell Entry Inhibitors by Drug Repurposing Using in silico Structure-Based Virtual Screening Approach. Frontiers in immunology 11, 1664.
Corbett KS, Flynn B, Foulds KE, Francica JR, Boyoglu-Barnum S, Werner AP, Flach B, O'Connell S, Bock KW, Minai M, Nagata BM, Andersen H, Martinez DR, Noe AT, Douek N, Donaldson MM, Nji NN, Alvarado GS, Edwards DK, Flebbe DR, Lamb E, Doria-Rose NA, Lin BC, Louder MK, O'Dell S, Schmidt SD, Phung E, Chang LA, Yap C, Todd JM, Pessaint L, Van Ry A, Browne S, Greenhouse J, Putman-Taylor T, Strasbaugh A, Campbell TA, Cook A, Dodson A, Steingrebe K, Shi W, Zhang Y, Abiona OM, Wang L, Pegu A, Yang ES, Leung K, Zhou T, Teng IT, Widge A, Gordon I, Novik L, Gillespie RA, Loomis RJ, Moliva JI, Stewart-Jones G, Himansu S, Kong WP, Nason MC, Morabito KM, Ruckwardt TJ, Ledgerwood JE, Gaudinski MR, Kwong PD, Mascola JR, Carfi A, Lewis MG, Baric RS, McDermott A, Moore IN, Sullivan NJ, Roederer M, Seder RA, Graham BS (2020) Evaluation of the mRNA-1273 Vaccine against SARS-CoV-2 in Nonhuman Primates. New England Journal of Medicine: NEJMoa2024671. DOI: DOI: 10.1056/NEJMoa2024671.

Coughlin M, Lou G, Martinez O, Masterman SK, Olsen OA, Moksa AA, Farzan M, Babcook JS, Prabhakar BS (2007) Generation and characterization of human monoclonal neutralizing antibodies with distinct binding and sequence features against SARS coronavirus using XenoMouse. Virology 361(1): 93-102.

Coutard B, Valle C, de Lamballerie X, Canard B, Seidah NG, Decroly E (2020) The spike glycoprotein of the new coronavirus 2019-nCoV contains a furin-like cleavage site absent in CoV of the same clade. Antiviral research 176: 104742.

Dahms SO, Jiao GS, Than ME (2017) Structural Studies Revealed Active Site Distortions of Human Furin by a Small Molecule Inhibitor. ACS Chemical Biology 12(5): 1211-1216.

Dai L, Zheng T, Xu K, Han Y, Xu L, Huang E, An Y, Cheng Y, Li S, Liu M, Yang M, Li Y, Cheng H, Yuan Y, Zhang W, Ke C, Wong G, Qi J, Qin C, Yan J, Gao GF (2020) A Universal Design of Betacoronavirus Vaccines against COVID-19, MERS, and SARS. Cell 182(3): 722-733.e11.

DeFrancesco L (2020) Whither COVID-19 vaccines? Nature Biotechnology 38(10):1132-1145.

Dhama K, Khan S, Tiwari R, Sircar S, Bhat S, Malik YS, Singh KP, Chaicumpa W, Bonilla-Aldana DK, Rodriguez-Morales AJ (2020a) Coronavirus Disease 2019-COVID-19. Clinical Microbiology Reviews 33(4):e00028-20.

Dhama K, Patel SK, Sharun K, Pathak M, Tiwari R, Yatoo MI, Malik YS, Sah R, Rabaan AA, Panwar PK, Singh KP, Michalak I, Chaicumpa W, Martinez-Pulgarin DF, Bonilla-Aldana DK, Rodriguez-Morales AJ (2020b) SARS-CoV-2 jumping the species barrier: Zoonotic lessons from SARS, MERS and recent advances to combat this pandemic virus. Travel Medicine and Infectious Disease 37:101830. 
Dhama K, Sharun K, Tiwari R, Dadar M, Malik YS, Singh KP, Chaicumpa W (2020c) COVID-19, an emerging coronavirus infection: advances and prospects in designing and developing vaccines, immunotherapeutics, and therapeutics. Human Vaccines and Immunotherapeutics 16(6):1232-1238.

Du L, He Y, Zhou Y, Liu S, Zheng BJ, Jiang S (2009) The spike protein of SARS-CoV--a target for vaccine and therapeutic development. Nature reviews. Microbiology 7(3): 226-236.

Du L, Yang Y, Zhou Y, Lu L, Li F, Jiang S (2017) MERS-CoV spike protein: a key target for antivirals. Expert Opinion on Therapeutic Targets 21(2), 131-143.

Duan J, Yan X, Guo X, Cao W, Han W, Qi C, Feng J, Yang D, Gao G, Jin G (2005) A human SARS-CoV neutralizing antibody against epitope on S2 protein. Biochemical and Biophysical Research Communications 333(1): 186-193.

Elmezayen AD, Al-Obaidi A, Şahin AT, Yelekçi K (2020) Drug repurposing for coronavirus (COVID-19): in silico screening of known drugs against coronavirus 3CL hydrolase and protease enzymes. Journal of Biomolecular Structure and Dynamics 1-13. DOI: https://doi.org/10.1080/07391102.2020.1758791.

Elshabrawy HA, Coughlin MM, Baker SC, Prabhakar BS (2012) Human monoclonal antibodies against highly conserved HR1 and HR2 domains of the SARS-CoV spike protein are more broadly neutralizing. PloS one 7(11), e50366.

Faslu Rahman C, Sharun K, Jose B, Sivaprasad M, Jisna K (2020). Animal Models for SARS-CoV-2 Infection: A Tool for Vaccine and Therapeutic Research. Trends in Biomaterials \& Artificial Organs 34(S3): 78-82.

Foged C (2011) Subunit vaccines of the future: the need for safe, customized and optimized particulate delivery systems. Therapeutic Delivery 2(8): 1057-1077.

Frediansyah A, Tiwari R, Sharun K, Dhama K, Harapan H (2020) Antivirals for COVID-19: A critical review. Clinical Epidemiology and Global Health, DOI: https://doi.org/10.1016/j.cegh.2020.07.006.

Fuller DH, Berglund P (2020) Amplifying RNA Vaccine Development. New England Journal of Medicine, 382(25):2469-2471.

Gao J, Lu G, Qi J, Li Y, Wu Y, Deng Y, Geng H, Li H, Wang Q, Xiao H, Tan W, Yan J, Gao GF (2013) Structure of the fusion core and inhibition of fusion by a heptad repeat peptide derived from the $\mathrm{S}$ protein of Middle East respiratory syndrome coronavirus. Journal of virology 87(24): 13134-13140.

Greenough TC, Babcock GJ, Roberts A, Hernandez HJ, Thomas WD Jr, Coccia JA, Graziano RF, Srinivasan M, Lowy I, Finberg
RW, Subbarao K, Vogel L, Somasundaran M, Luzuriaga K, Sullivan JL, Ambrosino DM (2005) Development and characterization of a severe acute respiratory syndrome-associated coronavirus-neutralizing human monoclonal antibody that provides effective immunoprophylaxis in mice. The Journal of infectious diseases 191(4): 507-514.

Han DP, Penn-Nicholson A, Cho MW (2006) Identification of critical determinants on ACE2 for SARS-CoV entry and development of a potent entry inhibitor. Virology 350(1): 15-25.

Han Y, Král P (2020) Computational Design of ACE2-Based Peptide Inhibitors of SARS-CoV-2. ACS nano 14(4): 5143-5147.

Hanson QM, Wilson KM, Shen M, Itkin Z, Eastman RT, Shinn P, Hall MD (2020) Targeting ACE2-RBD interaction as a platform for COVID19 therapeutics: Development and drug repurposing screen of an AlphaLISA proximity assay. bioRxiv : the preprint server for biology 2020.06.16.154708.

Hasan A, Paray BA, Hussain A, Qadir FA, Attar F, Aziz FM, Sharifi M, Derakhshankhah H, Rasti B, Mehrabi M, Shahpasand K, Saboury AA, Falahati M (2020) A review on the cleavage priming of the spike protein on coronavirus by angiotensinconverting enzyme-2 and furin. Journal of Biomolecular Structure \& Dynamics, DOI: 10.1080/07391102.2020.1754293.

He C, Qin M, Sun X (2020) Highly pathogenic coronaviruses: thrusting vaccine development in the spotlight. Acta pharmaceutica Sinica B 10(7): 1175-1191.

He Y, Li J, Li W, Lustigman S, Farzan M, Jiang S (2006) Crossneutralization of human and palm civet severe acute respiratory syndrome coronaviruses by antibodies targeting the receptorbinding domain of spike protein. Journal of immunology 176(10): 6085-6092.

Heaton PM (2020) The Covid-19 Vaccine-Development Multiverse. New England Journal of Medicine, NEJMe2025111.

Ho TY, Wu SL, Chen JC, Wei YC, Cheng SE, Chang YH, Liu HJ, Hsiang CY (2006) Design and biological activities of novel inhibitory peptides for SARS-CoV spike protein and angiotensinconverting enzyme 2 interaction. Antiviral research 69(2): 70-76.

Hoffmann M, Kleine-Weber H, Schroeder S, Krüger N, Herrler T, Erichsen S, Schiergens TS, Herrler G, Wu NH, Nitsche A, Müller MA, Drosten C, Pöhlmann S (2020a) SARS-CoV-2 Cell Entry Depends on ACE2 and TMPRSS2 and Is Blocked by a Clinically Proven Protease Inhibitor. Cell 181(2): 271-280.e8.

Hoffmann M, Schroeder S, Kleine-Weber H, Müller MA, Drosten C, Pöhlmann S (2020b) Nafamostat Mesylate Blocks Activation of 
SARS-CoV-2: New Treatment Option for COVID19. Antimicrobial agents and chemotherapy 64(6): e00754-20.

https://www.worldometers.info/coronavirus/. Accessed on $13^{\text {th }}$ October, 2020.

Hu H, Li L, Kao RY, Kou B, Wang Z, Zhang L, Zhang H, Hao Z, Tsui WH, Ni A, Cui L, Fan B, Guo F, Rao S, Jiang C, Li Q, Sun M, He W, Liu G (2005) Screening and identification of linear Bcell epitopes and entry-blocking peptide of severe acute respiratory syndrome (SARS)-associated coronavirus using synthetic overlapping peptide library. Journal of Combinatorial Chemistry 7(5): 648-656.

Huang X, Pearce R, Zhang Y (2020a) Computational design of peptides to block binding of the SARS-CoV-2 spike protein to human ACE2. bioRxiv : the preprint server for biology 2020.03.28.013607.

Huang Y, Yang C, Xu XF, Xu W, Liu SW (2020b) Structural and functional properties of SARS-CoV-2 spike protein: potential antivirus drug development for COVID-19. Acta pharmacologica Sinica 41(9): 1141-1149.

Hulswit RJ, de Haan CA, Bosch BJ (2016) Coronavirus Spike Protein and Tropism Changes. Advances in Virus Research 96, 29-57.

Hussain N, Ahmed A, Khan MI, Zhu W, Nadeem Z, Bilal M (2020) A real-time updated portrayal of covid-19 diagnosis and therapeutic options. Journal of Experimental Biology and Agricultural Sciences, 8(Spl-1- SARS-CoV-2): S21-S33. DOI: http://dx.doi.org/10.18006/2020.8(Spl 1- SARS-CoV-2).S21.S33.

Jackson LA, Anderson EJ, Rouphael NG, Roberts PC, Makhene M, Coler RN, McCullough MP, Chappell JD, Denison MR, Stevens LJ, Pruijssers AJ, McDermott A, Flach B, Doria-Rose NA, Corbett KS, Morabito KM, O'Dell S, Schmidt SD, Swanson PA 2nd, Padilla M, Mascola JR, Neuzil KM, Bennett H, Sun W, Peters E, Makowski M, Albert J, Cross K, Buchanan W, Pikaart-Tautges R, Ledgerwood JE, Graham BS, Beigel JH; mRNA-1273 Study Group (2020) An mRNA Vaccine against SARS-CoV-2 Preliminary Report. New England Journal of Medicine :NEJMoa2022483.

Jaimes JA, André NM, Chappie JS, Millet JK, Whittaker GR (2020a) Phylogenetic Analysis and Structural Modeling of SARSCoV-2 Spike Protein Reveals an Evolutionary Distinct and Proteolytically Sensitive Activation Loop. Journal of Molecular Biology 432(10): 3309-3325.

Jaimes JA, Millet JK, Whittaker GR (2020b) Proteolytic Cleavage of the SARS-CoV-2 Spike Protein and the Role of the Novel S1/S2 Site. iScience 23(6): 101212.
Jeyanathan M, Afkhami S, Smaill F, Miller MS, Lichty BD, Xing Z (2020) Immunological considerations for COVID-19 vaccine strategies. Nature Reviews. Immunology 20(10):615-632.

Ju B, Zhang Q, Ge J, Wang R, Sun J, Ge X, Yu J, Shan S, Zhou B, Song S, Tang X, Yu J, Lan J, Yuan J, Wang H, Zhao J, Zhang S, Wang Y, Shi X, Liu L, Zhao J, Wang X, Zhang Z, Zhang L (2020) Human neutralizing antibodies elicited by SARS-CoV-2 infection. Nature 584(7819):115-119.

Katsiki N, Banach M, Mikhailidis DP (2020) Lipid-lowering therapy and renin-angiotensin-aldosterone system inhibitors in the era of the COVID-19 pandemic. Archives of medical science :AMS 16(3): 485-489.

Keech C, Albert G, Cho I, Robertson A, Reed P, Neal S, Plested JS, Zhu M, Cloney-Clark S, Zhou H, Smith G, Patel N, Frieman MB, Haupt RE, Logue J, McGrath M, Weston S, Piedra PA, Desai C, Callahan K, Lewis M, Price-Abbott P, Formica N, Shinde V, Fries L, Lickliter JD, Griffin P, Wilkinson B, Glenn GM (2020) Phase 1-2 Trial of a SARS-CoV-2 Recombinant Spike Protein Nanoparticle Vaccine. New England Journal of Medicine NEJMoa2026920.

Keng CT, Zhang A, Shen S, Lip KM, Fielding BC, Tan TH, Chou CF, Loh CB, Wang S, Fu J, Yang X, Lim SG, Hong W, Tan YJ (2005) Amino acids 1055 to 1192 in the S2 region of severe acute respiratory syndrome coronavirus $\mathrm{S}$ protein induce neutralizing antibodies: implications for the development of vaccines and antiviral agents. Journal of virology 79(6): 3289-3296.

Khailany RA, Safdar M, Ozaslan M (2020) Genomic characterization of a novel SARS-CoV-2. Gene reports 19:100682.

Kim D, Lee JY, Yang JS, Kim JW, Kim VN, Chang H (2020) Architecture of SARS-CoV-2 Transcriptome. Cell 181(4): 914921.e10.

Lee N, McGeer A (2020) The starting line for COVID-19 vaccine development. Lancet 395(10240):1815-1816.

Li J, Ulitzky L, Silberstein E, Taylor DR, Viscidi R (2013) Immunogenicity and protection efficacy of monomeric and trimeric recombinant SARS coronavirus spike protein subunit vaccine candidates. Viral immunology 26(2): 126-132.

Li L, Petrovsky N (2016) Molecular mechanisms for enhanced DNA vaccine immunogenicity. Expert review of vaccines 15(3): 313-329.

Lip KM, Shen S, Yang X, Keng CT, Zhang A, Oh HL, Li ZH, Hwang LA, Chou CF, Fielding BC, Tan TH, Mayrhofer J, Falkner FG, Fu J, Lim SG, Hong W, Tan YJ (2006) Monoclonal antibodies 
targeting the HR2 domain and the region immediately upstream of the HR2 of the S protein neutralize in vitro infection of severe acute respiratory syndrome coronavirus. Journal of Virology 80(2): 941-50.

Liu S, Xiao G, Chen Y, He Y, Niu J, Escalante CR, Xiong H, Farmar J, Debnath AK, Tien P, Jiang S (2004) Interaction between heptad repeat 1 and 2 regions in spike protein of SARS-associated coronavirus: implications for virus fusogenic mechanism and identification of fusion inhibitors. Lancet (London, England) 363(9413): 938-947.

Liu T, Luo S, Libby P, Shi GP (2020) Cathepsin L-selective inhibitors: A potentially promising treatment for COVID-19 patients. Pharmacology \& Therapeutics 213: 107587.

Lu L, Liu Q, Zhu Y, Chan KH, Qin L, Li Y, Wang Q, Chan JF, Du L, Yu F, Ma C, Ye S, Yuen KY, Zhang R, Jiang S (2014) Structure-based discovery of Middle East respiratory syndrome coronavirus fusion inhibitor. Nature communications 5: 3067.

Lu R, Zhao X, Li J, Niu P, Yang B, Wu H, Wang W, Song H, Huang B, Zhu N, Bi Y, Ma X, Zhan F, Wang L, Hu T, Zhou H, Hu Z, Zhou W, Zhao L, Chen J, Meng Y, Wang J, Lin Y, Yuan J, Xie Z, Ma J, Liu WJ, Wang D, Xu W, Holmes EC, Gao GF, Wu G, Chen W, Shi W, Tan W (2020) Genomic characterisation and epidemiology of 2019 novel coronavirus: implications for virus origins and receptor binding. Lancet (London, England) 395(10224), 565-574.

Lurie N, Saville M, Hatchett R, Halton J (2020) Developing Covid-19 Vaccines at Pandemic Speed. New England Journal of Medicine 382(21):1969-1973.

Malik YS, Sircar S, Bhat S, Sharun K, Dhama K, Dadar M, Tiwari R, Chaicumpa W (2020) Emerging novel coronavirus (2019$\mathrm{nCoV}$ )-current scenario, evolutionary perspective based on genome analysis and recent developments. Veterinary Quarterly 40(1):68-76.

Masters PS (2006) The Molecular Biology of Coronaviruses. Advances in Virus Research 66:193-292.

Musarrat F, Chouljenko V, Dahal A, Nabi R, Chouljenko T, Jois SD, Kousoulas KG (2020) The anti-HIV drug nelfinavir mesylate (Viracept) is a potent inhibitor of cell fusion caused by the SARSCoV-2 spike (S) glycoprotein warranting further evaluation as an antiviral against COVID-19 infections. Journal of medical virology 6: 10.1002 .

Ng OW, Keng CT, Leung CS, Peiris JS, Poon LL, Tan YJ (2014) Substitution at aspartic acid 1128 in the SARS coronavirus spike glycoprotein mediates escape from a S2 domain-targeting neutralizing monoclonal antibody. PLoS One 9(7):e102415.
Ou X, Liu Y, Lei X, Li P, Mi D, Ren L, Guo L, Guo R, Chen T, Hu J, Xiang Z, Mu Z, Chen X, Chen J, Hu K, Jin Q, Wang J, Qian Z (2020) Characterization of spike glycoprotein of SARS-CoV-2 on virus entry and its immune cross-reactivity with SARSCoV. Nature communications 11(1): 1620.

Pandey SC, Pande V, Sati D, Upreti S, Samant M (2020) Vaccination strategies to combat novel corona virus SARS-CoV2. Life sciences 256: 117956.

Pang X, Cui Y, Zhu Y (2020) Recombinant human ACE2: potential therapeutics of SARS-CoV-2 infection and its complication. Acta Pharmacologica Sinica 41(9): 1255-1257.

Pardi N, Hogan MJ, Porter FW, Weissman D (2018) mRNA vaccines - a new era in vaccinology. Nature reviews. Drug discovery 17(4): 261-279.

Patel SK, Pathak M, Tiwari R, Yatoo MI, Malik YS, Sah R, Rabaan AA, Sharun K, Dhama K, Bonilla-Aldana DK, RodriguezMorales AJ (2020) A vaccine is not too far for COVID-19. Journal of Infection in Developing Countries 14(5):450-453.

Peiró C, Moncada S (2020) Substituting Angiotensin-(1-7) to Prevent Lung Damage in SARS-CoV-2 Infection?. Circulation 141(21): 1665-1666.

Pinto D, Park YJ, Beltramello M, Walls AC, Tortorici MA, Bianchi S, Jaconi S, Culap K, Zatta F, De Marco A, Peter A, Guarino B, Spreafico R, Cameroni E, Case JB, Chen RE, HavenarDaughton C, Snell G, Telenti A, Virgin HW, Lanzavecchia A, Diamond MS, Fink K, Veesler D, Corti D (2020) Structural and functional analysis of a potent sarbecovirus neutralizing antibody. bioRxiv: the preprint server for biology 2020.04.07.023903.

Poduri R, Joshi G, Jagadeesh G (2020) Drugs targeting various stages of the SARS-CoV-2 life cycle: Exploring promising drugs for the treatment of Covid-19. Cellular Signaling 74: 109721.

Ragia G, Manolopoulos VG (2020) Inhibition of SARS-CoV-2 entry through the ACE2/TMPRSS2 pathway: a promising approach for uncovering early COVID-19 drug therapies. European Journal of Clinical Pharmacology 1-8. doi: 10.1007/s00228-020-02963-4.

Rockx B, Corti D, Donaldson E, Sheahan T, Stadler K, Lanzavecchia A, Baric R (2008) Structural basis for potent crossneutralizing human monoclonal antibody protection against lethal human and zoonotic severe acute respiratory syndrome coronavirus challenge. Journal of virology 82(7): 3220-3235.

Rodriguez-Morales AJ, Bonilla-Aldana DK, Tiwari R, Sah R, Rabaan AA, Dhama K (2020b). COVID-19, an emerging 
coronavirus infection: current scenario and recent developments An overview. Journal of Pure and Applied Microbiology 14(1): 0512. https://doi.org/10.22207/JPAM.14.1.02

Rodriguez-Morales AJ, Dhama K, Sharun K, Tiwari R, BonillaAldana DK (2020a) Susceptibility of felids to coronaviruses. Veterinary Record 186(17):e21.

Romeo A, Iacovelli F, Falconi M (2020) Targeting the SARSCoV-2 spike glycoprotein prefusion conformation: virtual screening and molecular dynamics simulations applied to the identification of potential fusion inhibitors. Virus Research 286: 198068. DOI: 10.1016/j.virusres.2020.198068

Roshanravan N, Ghaffari S, Hedayati M (2020) Angiotensin converting enzyme-2 as therapeutic target in COVID-19. Diabetes \& Metabolic Syndrome 14(4): 637-639.

Rubin EJ, Baden LR, Morrissey S, (2020) Audio Interview: Covid19 Vaccine Development. New England Journal of Medicine 383(3): e40.

Samrat SK, Tharappel AM, Li Z, Li H (2020) Prospect of SARS$\mathrm{CoV}-2$ spike protein: Potential role in vaccine and therapeutic development. Virus research 288:198141. DOI: https://doi.org/10.1016/j.virusres.2020.198141.

Sanders JM, Monogue ML, Jodlowski TZ, Cutrell JB (2020) Pharmacologic Treatments for Coronavirus Disease 2019 (COVID-19): A Review. JAMA 323(18):1824-1836.

Shah STA, Iftikhar A, Khan MI, Mansoor M, Mirza AF, Bilal M (2020) Predicting covid-19 infections prevalence using linear regression tool. Journal of Experimental Biology and Agricultural Sciences 8(Spl-1- SARS-CoV-2) page S01 - S08. DOI: http://dx.doi.org/10.18006/2020.8(Spl 1- SARS-CoV-2).S01.S08.

Shang J, Wan Y, Luo C, Ye G, Geng Q, Auerbach A, Li F (2020a) Cell entry mechanisms of SARS-CoV-2. Proceedings of the National Academy of Sciences of the United States of America 117(21): 11727-11734.

Shang J, Ye G, Shi K, Wan Y, Luo C, Aihara H, Geng Q, Auerbach A, Li F (2020b) Structural basis of receptor recognition by SARS-CoV-2. Nature 581(7807): 221-224.

Sharun K, Dhama K, Patel SK, Pathak M, Tiwari R, Singh BR, Sah R, Bonilla-Aldana DK, Rodriguez-Morales AJ, Leblebicioglu $\mathrm{H}$ (2020c) Ivermectin, a new candidate therapeutic against SARSCoV-2/COVID-19. Annals of Clinical Microbiology and Antimicrobials 19(1):23.

Sharun K, Sircar S, Malik YS, Singh RK, Dhama K (2020a) How close is SARS-CoV-2 to canine and feline coronaviruses? Journal of Small Animal Practice 61(8):523-526.
Sharun K, Tiwari R, Dhama J, Dhama K (2020d) Dexamethasone to combat cytokine storm in COVID-19: Clinical trials and preliminary evidence. International Journal of Surgery 82:179-181.

Sharun K, Tiwari R, Iqbal Yatoo M, Patel SK, Natesan S, Dhama J, Malik YS, Harapan H, Singh RK, Dhama K (2020e) Antibodybased immunotherapeutics and use of convalescent plasma to counter COVID-19: advances and prospects. Expert Opinion on Biological Therapy 20(9):1033-1046.

Sharun K, Tiwari R, Patel SK, Karthik K, Iqbal Yatoo M, Malik YS, Singh KP, Panwar PK, Harapan H, Singh RK, Dhama K (2020b) Coronavirus disease 2019 (COVID-19) in domestic animals and wildlife: advances and prospects in the development of animal models for vaccine and therapeutic research. Human Vaccines and Immunotherapeutics 1-12.

Shin MD, Shukla S, Chung YH, Beiss V, Chan SK, Ortega-Rivera OA, Wirth DM, Chen A, Sack M, Pokorski JK, Steinmetz NF (2020) COVID-19 vaccine development and a potential nanomaterial path forward. Nature Nanotechnology. 2020 Aug;15(8):646-655.

Sivaprasad M, Jisna K, Sharun K, Faslu Rahman C, Faslu Rahman A (2020) Laboratory Diagnosis of COVID-19: Safety and Preventive Measures for Sample Processing. Trends in Biomaterials \& Artificial Organs 34(S3): 66-69.

Sternberg A, McKee DL, Naujokat C (2020) Novel Drugs Targeting the SARS-CoV-2/COVID-19 Machinery. Current topics in Medicinal Chemistry 20(16): 1423-1433.

Struck AW, Axmann M, Pfefferle S, Drosten C, Meyer B (2012) A hexapeptide of the receptor-binding domain of SARS corona virus spike protein blocks viral entry into host cells via the human receptor ACE2. Antiviral research 94(3): 288-296.

Sui J, Li W, Murakami A, Tamin A, Matthews LJ, Wong SK, Moore MJ, Tallarico AS, Olurinde M, Choe H, Anderson LJ, Bellini WJ, Farzan M, Marasco WA (2004) Potent neutralization of severe acute respiratory syndrome (SARS) coronavirus by a human $\mathrm{mAb}$ to $\mathrm{S} 1$ protein that blocks receptor association. Proceedings of the National Academy of Sciences of the United States of America 101(8): 2536-41.

Talreja H, Tan J, Dawes M, Supershad S, Rabindranath K, Fisher J, Valappil S, van der Merwe V, Wong L, van der Merwe W, Paton J (2020) A consensus statement on the use of angiotensin receptor blockers and angiotensin converting enzyme inhibitors in relation to COVID-19 (corona virus disease 2019). The New Zealand medical journal 133(1512): 85-87.

Tang T, Bidon M, Jaimes JA, Whittaker GR, Daniel S (2020) Coronavirus membrane fusion mechanism offers a potential target for antiviral development. Antiviral Research 178, 104792. 
Tetro JA (2020) Is COVID-19 receiving ADE from other coronaviruses?. Microbes and Infection 22(2): 72-73.

The Lancet (2020) Global governance for COVID-19 vaccines. Lancet 395(10241): 1883.

Tian X, Li C, Huang A, Xia S, Lu S, Shi Z, Lu L, Jiang S, Yang Z, Wu Y, Ying T (2020) Potent binding of 2019 novel coronavirus spike protein by a SARS coronavirus-specific human monoclonal antibody. Emerging Microbes \& Infections 9(1): 382-385.

Tiwari R, Dhama K, Sharun K, Iqbal Yatoo M, Malik YS, Singh R, Michalak I, Sah R, Bonilla-Aldana DK, Rodriguez-Morales AJ (2020) COVID-19: animals, veterinary and zoonotic links. Veterinary Quarterly 40(1):169-182.

Trezza A, Iovinelli D, Santucci A, Prischi F, Spiga O (2020) An integrated drug repurposing strategy for the rapid identification of potential SARS-CoV-2 viral inhibitors. Scientific Reports 10(1): 13866.

Tseng CT, Sbrana E, Iwata-Yoshikawa N, Newman PC, Garron T, Atmar RL, Peters CJ, Couch RB (2012) Immunization with SARS coronavirus vaccines leads to pulmonary immunopathology on challenge with the SARS virus. PloS one 7(4): e35421.

Ujike M, Nishikawa H, Otaka A, Yamamoto N, Yamamoto N, Matsuoka M, Kodama E, Fujii N, Taguchi F (2008) Heptad repeat-derived peptides block protease-mediated direct entry from the cell surface of severe acute respiratory syndrome coronavirus but not entry via the endosomal pathway. Journal of virology 82(1): 588-92.

Ulrich H, Pillat MM, Tárnok A (2020) Dengue Fever, COVID-19 (SARS-CoV-2), and Antibody-Dependent Enhancement (ADE): A Perspective. Cytometry, Part A : the journal of the International Society for Analytical Cytology 97(7): 662-667.

VanPatten S, He M, Altiti A, F Cheng K, Ghanem MH, Al-Abed Y (2020) Evidence supporting the use of peptides and peptidomimetics as potential SARS-CoV-2 (COVID-19) therapeutics. Future medicinal chemistry DOI: $10.4155 / \mathrm{fmc}-2020$ 0180. Advance online publication.

Walls AC, Park YJ, Tortorici MA, Wall A, McGuire AT, Veesler D (2020) Structure, Function, and Antigenicity of the SARS-CoV2 Spike Glycoprotein. Cell 181(2): 281-292.e6.

Walls AC, Tortorici MA, Snijder J, Xiong X, Bosch BJ, Rey FA, Veesler D (2017) Tectonic conformational changes of a coronavirus spike glycoprotein promote membrane fusion. Proceedings of the National Academy of Sciences of the United States of America 114(42): 11157-11162.
Wang C, Li W, Drabek D, Okba NMA, van Haperen R, Osterhaus ADME, van Kuppeveld FJM, Haagmans BL, Grosveld F, Bosch BJ (2020a) A human monoclonal antibody blocking SARS-CoV-2 infection. Nature communications 11(1):2251.

Wang C, Xia S, Zhang P, Zhang T, Wang W, Tian Y, Meng G, Jiang S, Liu K (2018) Discovery of Hydrocarbon-Stapled Short $\alpha$ Helical Peptides as Promising Middle East Respiratory Syndrome Coronavirus (MERS-CoV) Fusion Inhibitors. Journal of Medicinal Chemistry 61(5): 2026.

Wang Q, Zhang L, Kuwahara K, Li L, Liu Z, Li T, Zhu H, Liu J, Xu Y, Xie J, Morioka H, Sakaguchi N, Qin C, Liu G (2016) Immunodominant SARS Coronavirus Epitopes in Humans Elicited both Enhancing and Neutralizing Effects on Infection in Nonhuman Primates. ACS infectious diseases 2(5): 361-376.

Wang Q, Zhang Y, Wu L, Niu S, Song C, Zhang Z, Lu G, Qiao C, Hu Y, Yuen KY, Wang Q, Zhou H, Yan J, Qi J (2020b) Structural and Functional Basis of SARS-CoV-2 Entry by Using Human ACE2. Cell 181(4): 894-904.e9.

Wang X, Xia S, Wang Q, Xu W, Li W, Lu L, Jiang S (2020c) Broad-Spectrum Coronavirus Fusion Inhibitors to Combat COVID-19 and Other Emerging Coronavirus Diseases. International journal of molecular sciences 21(11): 3843.

Wang Y, Wang L, Cao H, Liu C (2020d) SARS-CoV-2 S1 is superior to the RBD as a COVID-19 subunit vaccine antigen. Journal of Medical Virology 10.1002/jmv.26320.

WHO (2020a) Weekly Epidemiological Update (28 September 2020) https://www.who.int/docs/defaultsource/coronaviruse/situation-reports/20200928-weekly-epiupdate.pdf?sfvrsn=9e354665_6 (Accessed on September 28, 2020)

WHO (2020b) Draft landscape of COVID-19 candidate vaccines. https://www.who.int/publications/m/item/draft-landscape-of-covid19-candidate-vaccines (Accessed on August 28, 2020)

Wrapp D, Wang N, Corbett KS, Goldsmith JA, Hsieh CL, Abiona O, Graham BS, McLellan JS (2020) Cryo-EM structure of the 2019nCoV spike in the prefusion conformation. Science 367(6483): 1260-1263 (2020).

Wu F, Zhao S, Yu B, Chen YM, Wang W, Song ZG, Hu Y, Tao ZW, Tian JH, Pei YY, Yuan ML, Zhang YL, Dai FH, Liu Y, Wang QM, Zheng JJ, Xu L, Holmes EC, Zhang YZ (2020a) A new coronavirus associated with human respiratory disease in China. Nature 579(7798): 265-269.

Wu Y, Li C, Xia S, Tian X, Kong Y, Wang Z, Gu C, Zhang R, Tu C, Xie Y, Yang Z, Lu L, Jiang S, Ying T (2020b) Identification of 
Human Single-Domain Antibodies against SARS-CoV-2. Cell host \& microbe 27(6): 891-898.

Wu Y, Wang F, Shen C, Peng W, Li D, Zhao C, Li Z, Li S, Bi Y, Yang Y, Gong Y, Xiao H, Fan Z, Tan S, Wu G, Tan W, Lu X, Fan C, Wang Q, Liu Y, Zhang C, Qi J, Gao GF, Gao F, Liu L (2020c) A noncompeting pair of human neutralizing antibodies block COVID-19 virus binding to its receptor ACE2. Science 368(6496):1274-1278.

Xia S, Yan L, Xu W, Agrawal AS, Algaissi A, Tseng CK, Wang Q, Du L, Tan W, Wilson IA, Jiang S, Yang B, Lu L (2019) A pancoronavirus fusion inhibitor targeting the HR1 domain of human coronavirus spike. Science advances 5(4):eaav4580.

Xia S, Zhu Y, Liu M, Lan Q, Xu W, Wu Y, Ying T, Liu S, Shi Z, Jiang S, Lu L (2020) Fusion mechanism of 2019-nCoV and fusion inhibitors targeting HR1 domain in spike protein. Cellular \& Molecular Immunology 17(7): 765-767.

Yamamoto M, Kiso M, Sakai-Tagawa Y, Iwatsuki-Horimoto K, Imai M, Takeda M, Kinoshita N, Ohmagari N, Gohda J, Semba K, Matsuda Z, Kawaguchi Y, Kawaoka Y, Inoue JI (2020) The Anticoagulant Nafamostat Potently Inhibits SARS-CoV-2 S Protein-Mediated Fusion in a Cell Fusion Assay System and Viral Infection In Vitro in a Cell-Type-Dependent Manner. Viruses 12(6): 629.

Yuan K, Yi L, Chen J, Qu X, Qing T, Rao X, Jiang P, Hu J, Xiong Z, Nie Y, Shi X, Wang W, Ling C, Yin X, Fan K, Lai L, Ding M, Deng H (2004) Suppression of SARS-CoV entry by peptides corresponding to heptad regions on spike glycoprotein. Biochemical and Biophysical Research Communications 319(3): 746-752.

Zhang G, Pomplun S, Loftis AR., Loas A, Pentelute BL (2020) The first-in-class peptide binder to the SARS-CoV-2 spike protein. bioRxiv: the preprint server for Biology 2020.03.19.999318
Zheng BJ, Guan Y, Hez ML, Sun H, Du L, Zheng Y, Wong KL, Chen H, Chen Y, Lu L, Tanner JA, Watt RM, Niccolai N, Bernini A, Spiga O, Woo PC, Kung HF, Yuen KY, Huang JD (2005) Synthetic peptides outside the spike protein heptad repeat regions as potent inhibitors of SARS-associated coronavirus. Antiviral therapy 10(3): 393-403.

Zheng M, Song L (2020) Novel antibody epitopes dominate the antigenicity of spike glycoprotein in SARS-CoV-2 compared to SARS-CoV. Cellular \& Molecular Immunology 17(5), 536-538.

Zhou Y, Yang Y, Huang J, Jiang S, Du L (2019) Advances in MERS-CoV Vaccines and Therapeutics Based on the ReceptorBinding Domain. Viruses11(1): 60

Zhu N, Zhang D, Wang W, Li X, Yang B, Song J, Zhao X, Huang B, Shi W, Lu R, Niu P, Zhan F, Ma X, Wang D, Xu W, Wu G, Gao GF, Tan W (2020a) China Novel Coronavirus Investigating and Research Team.,A Novel Coronavirus from Patients with Pneumonia in China, 2019. The New England journal of medicine 382(8): 727-733.

Zhu X, Liu Q, Du L, Lu L, Jiang S (2013) Receptor-binding domain as a target for developing SARS vaccines. Journal of thoracic disease 5 Suppl 2(Suppl 2):S142-148.

Zhu Y, Yu D, Yan H, Chong H, He Y (2020b) Design of Potent Membrane Fusion Inhibitors against SARS-CoV-2, an Emerging Coronavirus with High Fusogenic Activity. Journal of Virology 94(14): e00635-20.

Zhu Z, Chakraborti S, He Y, Roberts A, Sheahan T, Xiao X, Hensley LE, Prabakaran P, Rockx B, Sidorov IA, Corti D, Vogel L, Feng Y, Kim JO, Wang LF, Baric R, Lanzavecchia A, Curtis KM, Nabel GJ, Subbarao K, Jiang S, Dimitrov DS (2007) Potent cross-reactive neutralization of SARS coronavirus isolates by human monoclonal antibodies. Proceedings of the National Academy of Sciences of the United States of America 104(29): 12123-8. 